\author{
Abstracta Iranica \\ Abstracta Iranica Revue bibliographique pour le domaine irano-aryen \\ Volume 32-33 | 2013 \\ Comptes rendus des publications de 2009-2010
}

\title{
Pardis Minucheher. Writing in Tehran. The First Freedom of Press Law
}

\section{Bianca Devos}

\section{(2) OpenEdition \\ 12 Journals}

\section{Electronic version}

URL: http://journals.openedition.org/abstractairanica/40775

DOI: 10.4000/abstractairanica.40775

ISSN: 1961-960X

\section{Publisher:}

CNRS (UMR 7528 Mondes iraniens et indiens), Éditions de l'IFRI

\section{Printed version}

Date of publication: 1 December 2013

ISSN: 0240-8910

\section{Electronic reference}

Bianca Devos, «Pardis Minucheher. Writing in Tehran. The First Freedom of Press Law », Abstracta Iranica [Online], Volume 32-33 | 2013, document 292, Online since 01 July 2016, connection on 26 September 2020. URL : http://journals.openedition.org/abstractairanica/40775 ; DOI : https://doi.org/ $10.4000 / a b s t r a c t a i r a n i c a .40775$

This text was automatically generated on 26 September 2020.

Tous droits réservés 


\title{
Pardis Minucheher. Writing in Tehran. The First Freedom of Press
}

\section{Law}

\author{
Bianca Devos
}

\section{REFERENCES}

Pardis Minucheher. « Writing in Tehran. The First Freedom of Press Law », in :

Houchang E. Chehabi, Vanessa Martin, eds., Iran's Constitutional Revolution. Popular

Politics, Cultural Transformations and Transnational Connections. London, Tauris, 2010, p.

225-238. (Iran and the Persianate World)

1 This article about on Iran's first press law, enacted on 10 February 1908, sheds light on the intellectual, social and political context in which the bill of law was drafted. It traces discussions in the press preceding enactment and analyzes the views of early constitutionalist journalists, from whom publishing a newspaper was "the holiest and the best service for their country, a 'sacred' weapon" (p. 230) that could be used to curb abuses of power by the government. When the newspapers increasingly attacked state authorities and the shah, the government cracked down on the press. Restrictions of the press did not originate from the state alone however, but also from various social groups, such as radical anjomans. This lively debate on freedom of the press reflected general social tensions during the early constitutional period. 


\section{AUTHORS}

\section{BIANCA DEVOS}

Philipps-Universität, Marburg 